\title{
THE CENTER FOR ECONOMIC STUDIES 1982-2007: A BRIEF HISTORY
}

\author{
by
}

\author{
B.K. Atrostic* \\ U.S. Bureau of the Census
}

CES 09-35 September, 2009

The research program of the Center for Economic Studies (CES) produces a wide range of economic analyses to improve the statistical programs of the U.S. Census Bureau. Many of these analyses take the form of CES research papers. The papers have not undergone the review accorded Census Bureau publications and no endorsement should be inferred. Any opinions and conclusions expressed herein are those of the author(s) and do not necessarily represent the views of the U.S. Census Bureau. All results have been reviewed to ensure that no confidential information is disclosed. Republication in whole or part must be cleared with the authors.

To obtain information about the series, see www.ces.census.gov or contact Cheryl Grim, Editor, Discussion Papers, U.S. Census Bureau, Center for Economic Studies 2K130B, 4600 Silver Hill Road, Washington, DC 20233, Cheryl.Ann.Grim@census.gov. 


\begin{abstract}
More than half a century ago, visionaries representing both the Census Bureau and the external research community laid the foundation for the Center for Economic Studies (CES) and the Research Data Center (RDC) system. They saw a clear need for a system meeting the inextricably related requirements of providing more and better information from existing Census Bureau data collections while preserving respondent confidentiality and privacy. CES opened in 1982 to house new longitudinal business databases, develop them further, and make them available to qualified researchers. CES and the RDC system evolved to meet the designers' requirements. Research at CES and the RDCs meets the commitments of the Census Bureau (and, recently, of other agencies) to preserving confidentiality while contributing paradigmshifting fundamental research in a range of disciplines and up-to-the-minute critical tools for decision-makers.
\end{abstract}

Keywords: Microdata, history, research

* Any opinions and conclusions expressed herein are those of the author and do not necessarily represent the views of the U.S. Census Bureau. All results have been reviewed to ensure that no confidential information is disclosed. The author would like to thank the many current and former members of CES who contributed to this history, including Steve Andrews of the Bureau of Economic Analysis; Tim Dunne of the Federal Reserve Bank of Cleveland; John Haltiwanger of the University of Maryland; Brad Jensen of the McDonough School of Business, Georgetown University; and Brian Holly, Sang V. Nguyen, and Arnold Reznek of CES. 


\section{Introduction}

The Center for Economic Studies (CES) opened in 1982 to house new longitudinal business databases, develop them further, and make them available to qualified researchers. A generation of visionaries, including Census Bureau management and outside academic researchers, laid the foundation for the establishment of CES within the Census Bureau. Pioneering CES staff joined with qualified academic researchers who visited the Census Bureau to begin fulfilling those visions. Together, they improved and expanded the initial microdata files and added new microdata files and databases. CES staff and academic researchers began using the new data to produce analyses that contributed to a revolution of empirical work in the economics of industrial organization. The economic relevance of the growing body of CES research began to affect the development of official statistics, new longitudinal business databases, and economic research in the United States and other countries. CES and the Census Bureau identified a strategy_-research data centers (RDCs) — to expand researcher access to these important new data while maintaining the strict terms of access required by the Census Bureau's authorizing legislation, Title 13 of the U.S. Code.

The very existence of CES and RDCs, let alone their expansion and success, could not have happened without the continuing strong support of both the research community and senior management of the Census Bureau. CES has been particularly fortunate to have grown under a series of Associate Directors for Economic Programs whose vision and insights, as well as resources, allowed CES to surmount a series of challenges, and continue to grow.

This paper focuses on the years leading up to the creation of CES in 1982, and CES' first two decades. Because CES activities from 2000 through 2006 are discussed in recent CES and RDC research reports (U.S. Census Bureau 2005, 2006, and 2007), this paper highlights only major accomplishments and changes during this period.

\section{Visionaries, 1950s - 1982}

Decades of effort by far-sighted researchers and Census Bureau officials predate the emergence in 1982 of CES as a new organization within the Census Bureau. They saw the enormous potential analytical value of the considerable resources already invested by the Census Bureau and respondents to its censuses and surveys. As early as the 1950s, the Census Bureau, through an arrangement with the Social Science Research Council, sponsored a series of studies by economists such as Victor Fuchs, Michael Gort, Nancy Ruggles, and Richard Ruggles, analyzing internal economic census data (Report of Representatives to the Social Science Research Council 1960, Kallek 1982b). These analyses used primarily cross-section data or compared aggregates between two periods. Longitudinal analyses - linking records for the same businesses in multiple time periods - were considered during the same period. Conklin (1982) states "For nearly a quarter of a century, the Census Bureau has been attempting to create a reasonably adequate time series of longitudinal files for individual plants included in the Annual Survey of Manufactures," with Conklin and Nancy Ruggles and Richard Ruggles as strong advocates. Creating longitudinal data files required creating and keeping information in the survey and census files that would allow them to be linked. But that information was not always present. 
In 1964, the Census Bureau Advisory Committee of the American Economic Association addressed ways to increase researcher access to unpublished data. "One suggestion, already under study by the Bureau, is the creation of regional Census data centers at various universities, each having complete and corrected files of Census source data tapes” (Report of the Census Advisory Committee 1965). Two major issues cited then-meeting the legal requirement of preserving the confidentiality of the data, and the high cost of providing complete and correct data-would take decades to resolve.

In 1965, the Census Bureau and the National Science Foundation (NSF) initiated a project led by Harvard professor Zvi Griliches to begin matching the 1957-1965 annual NSF-Census Survey of Industrial Research and Development, collected by the Census Bureau, to the 1958 and 1963 Census of Manufacturing and Enterprise Statistics (Griliches 1980). Only Census Bureau employees had access to microdata, including the work of matching the data and producing complex econometric estimates. Regression results and other aggregate output were released to external researchers only after Census Bureau employees had reviewed them to be sure no confidential information was disclosed. The process was expensive and slow. A final draft was presented at a conference in 1975 (Griliches and Hall 1982).

Despite these problems, the potential usefulness of analyses based on the individual respondent records from Census Bureau surveys and censuses of businesses remained clear. Researchers had already shown the value of access to public-use respondent-level data such as the 1970 Decennial Census, and public-use versions of household surveys were increasingly available. The Census Bureau began making changes in its operating procedures to facilitate record-level linkages among business records as it realized that such linkages would also benefit its operations (Kallek 1982b and 1983). The Census Bureau continued to consider ways to make available additional analytically useful statistics that could be calculated from the underlying microdata (Kallek 1975). A new record-level linkage was made between the 1970 and 1971 Annual Surveys of Manufactures. An analysis conducted under the direction of Shirley Kallek, Associate Director for Economic Programs from 1974 through 1983, showed that the quintile distribution of productivity growth differed across establishment size classes (Kallek 1975). Kallek thanks two Census Bureau employees, Thomas Mesenbourg and William Menth, for their help in preparing the tabulation; Mesenbourg's association with CES continues to the present.

The Census Bureau persevered in working through the problems associated with developing microdata files from business data with such external researchers as Thomas Juster, Guy Orcutt, Harold Watts, and Nancy Ruggles, Richard Ruggles. One formal response was the economic research unit the Census Bureau established in the mid-1970s to prepare microdata analyses for other researchers on a reimbursable basis (Kallek 1975). The Census Bureau also charged that unit with exploring ways to link its internal household microdata to its business microdata (Kallek 1975). Linking records about individual workers to records from the businesses that employed them would allow analyses incorporating characteristics of both- "an entire new area which has never been tapped” (Kallek 1975). 


\section{Pioneers, 1982 - 1986}

Nancy Ruggles and Richard Ruggles, funded by the National Science Foundation, the Small Business Administration, and the Census Bureau, pioneered the development of a longitudinal database for U.S. manufacturing establishments from internal Census Bureau data (Kallek 1982a). A January 1982 workshop, Development and Use of Longitudinal Establishment Data, addressed methodological issues in developing it, confidentiality issues in use of such data by external researchers who were not paid Census Bureau employees, experiences in using longitudinal establishment data, and its potential.

At the workshop, Griliches and Hall commented that "The long-run difficulty in developing more extensive, detailed, and sophisticated analyses of Census-collected microdata sets is the absence of a strong in-house research arm at the Bureau itself, with its own programming and computer resources.” The workshop paper by Govoni (1982) noted the Census Bureau plan to establish an "economic research unit to prepare microdata analyses for others on a reimbursable basis should go a long way towards resolving the disclosure problem."

John R. (Randy) Norsworthy came to the Census Bureau as chief of the new economic research unit, CES, established in mid-1982. Norsworthy previously headed the Office of Productivity Analysis at the Bureau of Labor Statistics. The first CES staff members were Census Bureau economist Steve Andrews, who joined in June 1982, and programmer Jim Monahan, who joined a week later. Sang V. Nguyen, the first economist hired into the new organization, joined a month later, followed shortly by sociologist Craig Zabala, economist Peter Zadrozny, and Robert Bechtold, who became Assistant Chief. CES offices were in several locations of the main Census Bureau headquarters in Suitland, eventually settling in the 1500 wing.

A longitudinal business file soon became a reality. At an October 1984 conference sponsored by the Census Bureau and the National Science Foundation, Nancy Ruggles and Richard Ruggles reported on the development of the Longitudinal Establishment Database (LED) file containing manufacturing data for 1972 to 1981 (Ruggles and Ruggles 1984). An important innovation to the LED was the creation of a Permanent Plant Number (PPN) that made it easier to track an establishment as its ownership changed. The PPN and the Census File Number (CFN), which identified plants and the company that owned them, greatly expanded the ability to follow establishments and firms over time.

Researchers immediately began using the LED. In 1983, CES launched its Technical Notes series and its first series of Discussion Papers, both edited by Sang V. Nguyen.

\section{Research, recognition, and re-visioning, 1986 - 1992}

When Randy Norsworthy accepted a position on the faculty of Rensselaer Institute of Technology in 1986, Robert McGuckin came to the Census Bureau from the Justice Department to head CES. McGuckin built on the foundation Norsworthy laid. Charles (Chuck) A. Waite, who succeeded Shirley Kallek as Associate Director for Economic Programs following her death 
in 1983, continued to provide strong support for the young CES during his tenure, 1983 through 1994.

By 1988, the LED expanded to include the Economic Censuses of 1963 through 1982, and the Annual Survey of Manufactures for non-Census years from 1973 to 1985, updated as new years of data became available (McGuckin and Pascoe 1988). The expanded LED was named the Longitudinal Research Database (LRD). Much effort was spent developing PPNs for other microdata collected by the Census Bureau, such as the Census-NSF Research and Development data, and generating consistent industry and geography codes. The PPNs allowed these files to be linked to the core LRD. Analyses based on this new longitudinal linkage led to a series of publications on topics such as inventories, the structure of manufacturing industries, and the role of research and development.

CES expanded access to these new economic microdata in several ways. External researchers could submit computer programs to CES. CES staff would run the programs, review the output to avoid disclosing confidential information, and send approved output to the researcher (McGuckin and Pascoe 1988). CES, together with others in the Census Bureau, explored the potential for creating public-use microdata files from business data, but concluded that publicuse business data files that preserved the confidentiality of responses could not be created at that time (McGuckin and Nguyen 1990).

A third path was for external researchers to become Special Sworn Status employees (SSS) subject to the same confidentiality responsibilities and penalties as Census Bureau employees. Researchers came from academia, other government agencies, and private institutions. Their research often was conducted jointly with CES staff, as can be seen in the examples throughout this paper and in the CES Discussion Paper series. Consistent with the requirements of the Census Bureau's enabling legislation, Title 13 of the U.S. Code, access to internal microdata by such outside researchers is required to provide benefits to the Census Bureau.

The American Statistical Association (ASA)/NSF/Census Bureau Research program was an important source of support for external researchers at CES during these years. The Research program sponsored both Research Fellows (established researchers) and Research Associates (usually advanced graduate students or recent Ph.D.s). In 1990, for example, CES had six ASA/NSF/Census fellows, 11 staff researchers, and 21 external researchers. The Research program's support of Research Associates helped CES create an on-going intellectual community that continues to train new generations of empirical researchers.

Many researchers who came to CES through the ASA/NSF/Census Research program continued their association with CES for decades. Two examples-Mark Roberts and Michael Gortillustrate the experiences and contributions of a much broader range of researchers. Mark Roberts came to CES from Pennsylvania State University in 1985 as one of CES' first Fellows. Roberts has remained an active RDC researcher, with CES Discussion Papers spanning 1992 through 2007, and became a member of the Census Advisory Committee. Roberts brought Tim Dunne to CES as his research assistant in 1985, beginning an association with CES that continued as Dunne completed his own dissertation, became an ASA/NSF/Census Fellow, was an RDC researcher, then returned to CES as Research Director, 1997 through 1999. Dunne's 
early work examining the quality of PPNs identified and corrected thousands of likely errors. Students of both Roberts and Dunne have become RDC researchers. Michael Gort, who had been among the academics conducting some of the earliest microdata research at the Census Bureau in the 1950s, came to CES as a Fellow in 1989. His students have become RDC researchers. Gort, too, became a member of the Census Advisory Committee for a number of years, and contributed a CES Discussion Paper as recently as 2003.

New data and expanded access led to more empirical research on topics such as mergers and acquisitions, high technology trade, plant-level productivity, and entry and exit of firms (Pascoe and McGuckin 1988). CES continued the long-standing tradition of collaboration between Census Bureau staff and outside scholars. The first Technical Paper, issued in 1989, was coauthored by Boston College researcher Frank Gollop and CES staff member James Mohahan (Gollop and Monahan 1989). See Text Box 1. Aggregate data showed that firms had been becoming increasingly diversified in terms of the kinds of output they produced. The paper used the new microdata to identify sources of this diversity and found that plants were becoming homogeneous. Firm-level diversity was being driven by a trend towards firms operating multiple plants, not by increasing heterogeneity in the output of those plants.

McGuckin's initiatives sought to increase awareness of CES research accomplishments and their contributions to the work of the Census Bureau. The CES seminar series began in 1987, organized initially by Sang V. Nguyen. CES restarted its Discussion Paper series in 1988, with Sang V. Nguyen again as editor. The Discussion Papers series had four papers in 1988, grew to 16 in 1992, and remained in the mid- to upper-teens through 1999. McGuckin instituted an annual research report in 1988. The report, edited by CES researcher Arnold Reznek from 1990 to 1999 , was distributed to the CES research community, potential researchers, stakeholders, and decision-makers.

The earliest surviving report, from 1989, established several characteristics of CES research that continue to the present. First, the report states clearly on the first page the legal requirement that work conducted by SSSs must benefit the Census Bureau's statistical program. Second, the report documents a diverse range of active research topics. Research is grouped into seven broad programs (organization and behavior of firms and markets; labor market issues; production, productivity growth and technical change; minority business; international issues; statistical issues; and data and computer program development). While there have been changes over the years in the groupings under which research at CES and the RDCs is categorized, with additions and deletions, research continues on most of these early topics. 


\section{Text Box 1}

McGuckin's foreword to Gollop and Monahan (1989) succinctly states the view of the economics profession on the problems of data access and illustrates how well the new venture was solving them.

"In perhaps the best known and most widely read text on industrial organization, F.M. Scherer in discussing diversification research based on confidential census data, published in 1962, comments that:

'The Census Bureau has ceased granting such access to outside scholars. ... The data, collected at an expense of tens of millions of dollars, lie unanalyzed in Census Bureau files. Though less apt to draw headlines than Congressional junkets and the overpayment of welfare recipients, this state of affairs is equally wasteful.'

This passage was taken from the second edition of Scherer's book entitled Industrial Market Structure and Economic Performance published in 1980. Since that time substantial research on a wide range of industrial organization, productivity, and econometric issues have been undertaken by economists working at or with the Center for Economic Studies at the Census Bureau. The Center was formed in 1982 to facilitate, among other things, research by outside scholars.

In view of Scherer's comments, it is fitting that the Center's first monograph is about diversification and was written jointly by an outside scholar (Frank Gollop) in collaboration with a Center staff member (James Monahan). Gollop and Monahan provide an important empirical analysis of the extent and nature of diversification in U.S. manufacturing industries. The authors develop, at various levels of industrial detail, comparable measures of diversification at five-year intervals over the 1963 through 1982 period. They also develop an index of diversification with very desirable properties. The index is a clear improvement over previous measures of diversification.

Although the authors present a number of interesting findings, one result stands out. Since 1963 diversification has been increasingly associate with firms which operate multiple plants, rather than with plants which produce a variety of products. Thus, Gollop and Monahan find that although plant-level diversification has been decreasing over time, firm-level diversification has been increasing.

The monograph, From Homogeneity to Heterogeneity: An Index of Diversification, represents a significant step in the study of diversification. It also represents a new commitment by the Census Bureau to outside scholars in furthering its mission to profile the nation's institutions.”

Scherer later become an ASA/NSF/Census Fellow and a member of the Census Advisory Committee. A book and a journal article were produced from his research using CES data. The passage cited above does not appear in the third (1990) edition of his textbook. 
The value of greater access to internal economic microdata quickly revealed itself in the coin of the research realm: papers and publications. CES staff and Special Sworn Status researchers published 64 papers in 1991 alone (U.S. Census Bureau 1991). CES research findings on the diversity and differential dynamism of businesses showed the convenient analytical construct of the "representative firm" to be fatally flawed. The implications of the new research caught the attention of the academic community. Nobel Laureate Ronald Coase, who visited CES in 1992, noted in his December 1991Nobel Lecture:

\begin{abstract}
"Nor should we forget the work now getting started at the Center for Economic Studies of the Bureau of the Census. This greater availability of data and the encouragement given to all researchers working on the institutional structure of production by the award to me of the Nobel Prize, should result in a reduction in that elegant but sterile theorizing so commonly found in the economics literature on industrial organization and should lead to studies which increase our understanding of how the real economic system works."
\end{abstract}

With the value of access to internal microdata established, Bob McGuckin in 1992 presented to the Census Bureau's senior executives a strategy to increase access for external researchers. Census Bureau facilities could be established in universities or similar institutions around the country, or CES facilities could be created in existing Census Bureau regional offices (McGuckin 1992).

\title{
5. Expanding horizons, 1992 - 1999
}

McGuckin’s 1992 proposals for expanding researcher access to CES data took root. In 1994, in partnership with the National Science Foundation, the first remote Research Data Center was established in the Census Bureau's Boston Regional Office. The opening of the Boston RDC expanded the kinds of microdata researchers could access. Research by Jeffrey Liebman of Harvard University used household data — data from the Survey of Income and Program Participation (SIPP) linked to data from the Internal Revenue Service and the Social Security Administration - to study distributional effects of the Social Security system (Liebman 2002, Feldstein and Liebman 2002). Internal data from the American Housing Survey (AHS) were made available for research conducted by Jeffrey Zabel that analyzed the economic and social factors determining the neighborhoods where people decided to live, and the price of housing in those neighborhoods (Ioannides and Zabel 2002, Kiel and Zabel 2004).

The RDC system expanded quickly in both sites and data. The next RDC to open was the Carnegie-Mellon, in 1997. Brad Jensen, a CES researcher, became its Executive Director. The National Consortium on Violence Research (NCOVR), also based at Carnegie-Mellon, had opened in 1995. At the request of the Bureau of Justice Statistics, the Census Bureau provided microdata from the National Prisoner Statistics Program and the National Crime Victimization Survey for use by NCOVR researchers at the Carnegie-Mellon RDC. Internal microdata from the 1990 decennial census were made available to Carnegie-Mellon RDC researchers.

CES researchers continued to expand the LRD. For example, work by Dunne and Doms in 1991 added economic variables such as capital stocks, input and output deflators, energy indices, and 
wage rates, to the LRD. Establishments within a firm were linked together into the Manufacturing Plant Ownership Change Database (Nguyen 1999). The linkages allow researchers to study the effects on a business' economic performance of mergers and acquisitions activity (e.g. McGuckin, Nguyen, and Reznek 1995; and Phillips and Maksimovic 2001).

Following the success of the manufacturing-based LRD, researchers at the Census Bureau began developing a longitudinal database covering nearly all of the non-farm private economy, and some activities in the public sector, in the late 1990s. The Longitudinal Business Database (LBD) was created by linking the Standard Statistical Establishment List (SSEL) and Economic Censuses. The LBD provides basic information for nearly all establishments and firms with paid employees in all sectors. However, the LBD does not have the depth of information available for the manufacturing sector in the LRD. The process of creating the LBD identified and repaired errors in the longitudinal linkages in the LRD. Like the LRD, the LBD is designed so that researchers can link it to other Census Bureau surveys and censuses of businesses (Miranda and Jarmin 2002).

Existing research databases continued to be improved, and new ones were developed from other business censuses and surveys, including quarterly financial reports, research and development, characteristics of business owners, environmental data, and energy use in manufacturing. The CES research report for 1993-94 lists 22 databases. Two examples illustrate the breadth of the research topics for which CES researchers were developing micro databases. First, the Characteristics of Business Owners (CBO) database was created from the CBO survey conducted by the Census Bureau in 1982 and 1987 (Nucci 1989), updated to include the 1992 CBO survey (Headd 1999). Using the CBO database, researchers can relate detailed information about the demographic characteristics of people who start businesses, and the businesses (for example, industry, financing, exports, franchising) to the success or failure of the businesses. Second, the Pollution Abatement Costs and Expenditures Survey (PACE) database was created by linking PACE survey microdata to the LRD (Streitwieser 1996). The initial PACE database included the annual PACE survey from 1979 to 1993 (except 1983 and 1987). The PACE was discontinued after 1994, but collected in a substantially different form in 1999. A study by CES and RDC researchers documented changes in the survey over time and provided a guide to comparisons between the two years of survey data (Becker and Shadbegian 2005).

Another dimension was added to CES’ portfolio in the early 1990s: projects that provided benefits both to the Census Bureau and to other federal agencies. Such projects took on a number of forms. In some cases, ongoing research agendas and interagency relationships were formalized. For example, a series of researchers had created a research and development (R\&D) database. The R\&D database described in Adams and Peck 1994 built on the pre-CES era work begun by Griliches (1982) and continued by CES researcher Andrews and others (Guerard, Bean, and Andrews 1987). Analyses and insights from building and using the R\&D database, and close work with survey staff, resulted in proposals for changes that were considered by the survey sponsor, the National Science Foundation (Adams and Champion 1992). Further research by Hall and Long evaluated the survey data by comparing it to data for companies that were required to file R\&D data with the Securities and Exchange Commission on form 10-K (Hall and Long 1999). More recently, the R\&D survey data were linked with NBER Patent Dataset, providing "an unprecedented view of the R\&D-to-patenting innovation process” (Kerr and Fu 
2006). CES staff have continued to work with the Census Bureau offices that conduct the Survey of Industrial Research and Development that forms the core of the R\&D database.

Mutual benefit could result from having staff of agencies that sponsor surveys collected by the Census Bureau become SSS and analyze the underlying historical survey microdata at CES. For example, since the mid-1990s, the Federal Reserve Board has been conducting research at CES to improve the Industrial Production Index, which is based on the Survey of Plant Capacity. Staff from the Federal Reserve Board also work closely with the Census Bureau program area staff that conduct that survey. This collaboration has resulted in the development of a new quarterly survey of plant capacity that began in the first quarter of 2007. In addition, Federal Reserve Board staff conduct research on a range of topics. Some of that research is conducted jointly with CES staff.

CES' ability to support wide-ranging analyses was an important reason that the Department of Education selected the Census Bureau to conduct a new survey of employer training practices, the National Employer Survey (NES). The NES was conducted in 1994, 1996, 1997, 1998, and 2000. A series of studies analyzed the impact of workplace practices and innovation on productivity and workplace outcomes (e.g., Cappelli 1997, a series of papers by Black and Lynch (e.g., 2001, 2005), and Lynch 2007).

Collaboration between CES and the Census Bureau's program areas received support from the Census Bureau's senior management. The American Economic Association members of the Census Advisory Committee recognized the potential of collaboration to improve both aggregate statistics and the readiness of the underlying microdata for research use. Staff worked on the then-new Medical Expenditure Panel Survey Insurance Component (MEPS-IC), and became participants in planning meetings for the Economic Census and the Annual Survey of Manufactures.

CES staff and RDC researchers contributed a range of analyses that were important to the development of the North American Industry Classification System (NAICS), designed to replace the Standard Industrial Classification (SIC) system used to categorize business units. For example, CES helped develop a matrix characterizing how economic data are grouped under the SIC and identifying potentially more consistent or useful groupings (Triplett, Kennet, Jarmin, Gollop 1998). The matrix was based on part of the diversification developed in Gollop and Monahan 1989. Once the final NAICS specification had been adopted, CES researchers worked with program area staff to incorporate NAICS into existing Census Bureau data. CES researchers and researchers from the Federal Reserve Board created a way to make industry coding in CES microdata that was consistent over time (Bayard and Klimek 2004). Consistent coding allowed Federal Reserve Board economists to construct a NAICS-based version of the Index of Industrial Production back to 1972.

Mutual benefit could also be provided by analyses that CES staff conducted under contract to an agency. CES researcher Mary Streitwieser conducted work for the Department of Energy that combined several sources of data on energy use to develop a better understanding of the energy consumed by industries. The resulting report formed the basis of Congressional testimony by officials of the Department of Energy (Streitwieser 1993). A notable example is the joint work 
CES undertook with the Manufacturing Extension Partnership Program (MEP) of the National Institute of Standards and Technology (NIST). The MEP provided technical and business assistance to small and medium-sized businesses through a series of manufacturing extension centers around the country, similar to the assistance that county extension agents provide to farmers. One component of the MEP was a monthly follow-up survey directed by CES researcher Brad Jensen. Records from the MEP program were also matched with the LRD to provide measures of plant performance, and to provide a scientifically balanced sample for analyzing the MEP. Evaluations of the MEP program were conducted using the MEP-LRD database (see for example Jarmin 1999). Labor productivity growth was 3.4 to 16.0 percent faster at plants that were MEP clients (Jarmin 1999).

The 1996 publication of Job Creation and Destruction, by RDC researchers John Haltiwanger, and Scott Schuh, together with Steven Davis (Davis, Haltiwanger, and Schuh 1996), received enthusiastic critical reviews within the economics profession and was widely cited in the business press. The authors use the LRD to document the heterogeneity and dynamism of the U.S. business sector. Their analysis shatters the convenient analytical fiction of the "typical" firm and underlines the importance of analyzing microdata to understand industries and economies. A draft of the book was released shortly before the Group of 7 (G-7) Jobs Conference in Detroit in March 1994 (Davis, Haltiwanger, and Schuh 1994). Its findings formed the basis of the U.S. presentation at the G-7 conference and the resulting call for further research on job creation and job loss.

The book subsequently affected the development of official statistics and economic research in G-7 and OECD countries and expanded horizons for CES and RDC researchers. The demonstrated value to economic analysis of longitudinal panels of U.S. business data led to a major international conference held in Washington, D.C., in 1995, “The Effects of Technology and Innovation on Firm Performance and Employment.” New longitudinal panels of business data subsequently were created in many of these countries. New data sparked on-going series of studies and international conferences using these new microdata, beginning with the first Conference on the Analysis of Establishment micro Data (CAED), held in Helsinki Finland in 1996. CAED conferences, held every year or two since, alternate between Europe and the United States and draw microdata research practitioners from an expanding number of countries (Bartelsman, Doms, and Laaksonen 2008).

Frederick T. Knickerbocker (“Dr. Knick”) succeeded Chuck Waite as Associate Director for Economic Programs in 1995 following Waite's retirement in 1994. Knickerbocker's vision and advocacy of CES throughout his ten-year tenure were crucial to the continuing development and existence of CES, its data, and the RDC program.

After a decade at CES, McGuckin left to become Director of Research at the Conference Board in New York City in 1996. CES moved from Census Bureau headquarters to an office building several miles away, in Upper Marlboro, MD. John Haltiwanger of the University of Maryland became the Census Bureau's first Chief Economist, and the head of CES, in 1997. Tim Dunne returned to CES from the University of Oklahoma for two years as Director of Research, 1997 1999. Dunne continued building and documenting the LRD, and building CES. 
Haltiwanger describes his experiences at CES, including his leadership era, in his introduction to the 2007 CES annual research report (U.S. Census Bureau, 2008). The value of those contributions to the Census Bureau was widely recognized. The Census Advisory Committee of Professional Associations awarded Haltiwanger a statement of appreciation. When Haltiwanger's two-year term as Chief Economist ended and he returned to the University of Maryland, the CES Annual Report 1998-1999 contained a statement from Frederick T. Knickerbocker on "John Haltiwanger's Legacy for the Census Bureau.” Knickerbocker noted that, while the Census had hired Haltiwanger to provide intellectual guidance, much of his work involved institution building by formalizing the system for expanding the RDC system, expanding the use of household microdata in the RDCs, and supporting efforts urging the Census Bureau to support research on linking household and business data.

\section{Managing growth, 1999 - 2006}

Brad Jensen returned to CES as Director in August 1999. Jensen's tenure saw the fruits of the formalized RDC expansion plans. The UCLA and Berkeley RDCs opened in the summer of 1999, followed by the Triangle RDC in September 2000. Two more RDCs opened in 2002: Michigan in September and Chicago in December. In 2004, the CMU RDC closed by mutual agreement between the Census Bureau and CMU, and the Cornell RDC opened. The most recent expansion was the RDC at Baruch College, New York City, which opened in 2006.

\section{1 More Microdata for Research}

The data sets available to CES and RDC researchers continued to grow. Sectors outside manufacturing were added to the manufacturing-focused LRD, creating the Longitudinal Business Database (LBD), which currently covers almost 24 million unique establishments from 1976 through 2005. Businesses without workers may precede businesses with workers. Work began to expand the LBD to include businesses without workers-nonemployers - in all sectors to allow better understanding of the factors underlying the formation and growth of businesses with workers (Miranda and Jarmin 2002). This Integrated Longitudinal Business Database (ILBD), developed with the support of the Census Bureau and the Kauffman Foundation, contains the universe of all U.S. business establishments with and without paid employees, or more than 20 million records per year for 1977, 1982, 1987, 1992, and 1994-2005. Links allow the ILBD to be integrated with the LBD and Economic Censuses.

A new agreement with the Agency for Healthcare Research and Quality (AHRQ) brought data from the new Medical Expenditure Panel Survey-Insurance Component (MEPS-IC), which the Census Bureau collects for AHRQ, to the RDCs. The MEPS-IC, discussed in detail in (U.S. Census Bureau, 2008), collects information on health insurance plans offered through employers from about 25 thousand establishments annually. Data currently are available for 1996 through 2004. CES staff economists support the MEPS-IC collection effort and conduct research using the microdata.

More household data became available. Microdata from internal versions of the Survey of Income and Program Participation (SIPP) through 1996 were delivered to CES in 1998. Internal versions of the Census 2000 one hundred percent and sample files (also known as "short" and "long-form” files) became available in 2003. Data from the new American Community Survey 
first became available in 2005. More years of data, both recent and historical, have been added to most of the household surveys. CES funded work to develop documentation for the Census Bureau's flagship household surveys, the CPS March supplement (recently expanded and known as the Annual Social and Economic Supplement, or ASEC), and SIPP.

As Kallek noted in 1975, the economic research community had long wanted microdata that would allow modeling of both the employer and worker sides of the labor market. An early CES project linked workers in manufacturing industries in the Current Population Survey (CPS) to employers in the LRD (e.g., Davis and Haltiwanger 1991). Beginning in the early 1990s, CES projects linked information about workers from the 1990 Decennial Census sample files-many more workers than in the CPS - to information about the businesses in the LRD at which they worked. The first test phase expanded to a full-blown project that, like the LRD, was limited to manufacturing. The Worker-Establishment Characteristics Database (WECD) linked roughly 200 thousand workers and 16 thousand manufacturing establishments (Troske 1995). When the LRD expanded into other sectors, the worker-establishment linkage effort followed suit. RDC researchers improved the matching techniques until the final data file, known as the 1990 Decennial Employer-Employee Database (DEED), linked nearly 4 million workers to over 1 million establishments (Bayard et al. 2002).

New products from the Census Bureau's Longitudinal Employer and Household Dynamics (LEHD) program, linking worker and employer records from a variety of Census Bureau data sources and state unemployment insurance programs, became available to RDC researchers in 2005. The evolving LEHD data greatly expand the range of longitudinal worker-employer dynamics that CES and RDC researchers can analyze. For example, the LEHD Employer Quarterly Workforce Indicators data described on the current CES Web site provides information on the gender and age of the workforce for approximately 4 million establishments in more than 20 states for 1990 through 2003, with years varying by state. The LEHD program now includes 49 states, and the data available to RDC researchers will increase correspondingly.

\subsection{Managing Under New Rules}

The Census Bureau has long-standing concerns about the best way to provide researchers with access to microdata for analyses while also maintaining the required confidentiality of respondent information, as stated, for example, in Kallek 1975 and 1982a. The Census Bureau requires external researchers to become SSS employees, sworn to uphold the same confidentiality requirements, and subject to the same significant penalties, as Census Bureau employees (see, for example, McGuckin 1992). However, concerns about preserving privacy and confidentiality of respondent data in the face of ever-increasing computing capabilities (e.g., Duncan, Jabine, and de Wolf 1993) heightened in the late 1990s as computing costs fell and the Internet became a widely used tool (e.g., Doyle, Lane, Theeuwes, and Zayatz 2001).

In 1999, the Internal Revenue Service (IRS) conducted its required triennial review of the confidentiality safeguards applied to IRS data at the Census Bureau. The review raised some concerns that potentially disrupted the Census Bureau's ability to use tax data, and so, to produce fundamental statistics about businesses (see, for example, Greenia 2004 and Davis and Holly 2006). As a result of the review, a number of RDC research projects were suspended. 
Subsequent discussions between the agencies were difficult, but ultimately resulted in an interagency agreement in 2000, Criteria for the Review and Approval of Census Projects that Use Federal Tax Information, known as the Criteria Document. The Criteria Document specified the requirements for access to IRS data at the Census Bureau, which includes most data from businesses. CES posted the Criteria Document on its Web site and incorporated the Document's requirements in its proposal submission and review process. All CES and RDC projects using tax data meet those requirements. Once CES approves projects using tax data, they are sent to the IRS for a second required review to ensure that the project meets the "predominant purpose" standard specified in the Criteria Document.

"The 1999 IRS safeguard review was a watershed experience for the CES and all its stakeholders. Many users of the RDC system stood by the [Census] Bureau in the difficult period following the review, and they have helped to strengthen the program such that it is now viewed by executive staff at Census as a corporate resource whose role is much larger than previously envisioned.” (Davis and Holly 2006).

To improve its ability to manage and track DC research, Jensen asked CES programmers James Monahan and William Yates to create an on-line proposal submission and management system. CES began using the system in 2000. The system continues to expand to accommodate both new requirements and enhancements that make the system easier to use for both CES staff and external researchers. Emphasizing how important it was to CES to manage the volume and diversity of proposals, CES added a new full-time position, the Project Review Coordinator, in 2001. The Project Review Coordinator organizes the review and approval of RDC research proposals, and tracks the status and products produced from approved projects. Brian Holly joined CES as Project Review Coordinator in December of that year.

Brad Jensen left CES in 2003 to join the Petersen Institute for International Economics. Ron Jarmin became Acting Chief until Dan Weinberg was appointed Chief Economist and Chief of the Center for Economic Studies in December 2004. CES continued to receive strong support from the Census Bureau. Thomas Mesenbourg, who succeeded Knickerbocker as Associate Director for Economic Programs when Knickerbocker retired in 2005, had contributed advice, guidance, and resources to CES in his previous role as Assistant Director for Economic Programs.

The initial experience as CES, the Census Bureau, and IRS began applying the Criteria Document to new RDC research proposals made it clear that researchers and reviewers alike needed more formal guidance about what the criteria meant. Weinberg led a series of initiatives to address these problems. A primer on writing a convincing statement of how the proposed research would benefit the Census Bureau had been written by an interdivisional team led by CES researcher B.K. Atrostic, and including CES researcher Sang V. Nguyen. In 2003, the Census Bureau's Data Stewardship Executive Policy Committee adopted a document including the primer and four additional criteria that apply only to proposals using household data, that is, data that are confidential under Title 13 but not under Title 26. CES posted the new guidance on its Web site. CES compiled a list of methodological research topics that Census Bureau staff identified as potentially benefiting their programs. The list is posted on the CES Web site. 
CES increased its efforts to capture and disseminate the results of research in the RDC system. Annual CES research reports describing CES and RDC accomplishments were re-instituted, beginning with a combined report for 2000-2004, edited by CES researcher B.K. Atrostic. The CES Discussion Paper series expanded. From 2005 forward there are 30 or more papers a year, a strong increase over the 15 to 20 papers typical of most of the preceding decade.

To provide value to more parts of the Census Bureau, and to expand the pool of potential RDC researchers, CES continued to expand the data available to RDC researchers. An effort spearheaded by Weinberg led to agreements on the use of internal data from other federal agencies in the RDCs, as described in (U.S. Census Bureau, 2008). Weinberg also strengthened the relationship between CES and the RDCs and the operating divisions of the Census Bureau, and the status of CES within the Census Bureau was raised to a formal Division.

Weinberg encouraged CES and its partners in the proposal review process to find ways to streamline it and reduce review time. An important development in that effort was the memorandum that Census Bureau Director Kincannon issued in January 2007 specifically mentioning the value to the Census Bureau of research conducted by external researchers at the RDCs (U.S. Census Bureau 2007). CES posted the letter on its Web site. Within a few months, Weinberg noted in his introduction to the 2006 annual research report, there was marked improvement in IRS review time. Approval processes with several other internal and external stakeholders also became shorter and smoother. However, complex projects, such as those using linked household data sets, remain likely to have lengthy review times.

At the April 2007 meeting of the Census Advisory Committees of Professional Associations, the American Economic Association members commended the Census Bureau and the RDCs for reducing proposal review time. The members also viewed Kincannon's letter acknowledging the value of research at RDCs for advancing the mission of the Census Bureau as a favorable development.

Recognizing that CES had significantly streamlined the review process for RDC proposals, the Census Bureau in 2007 made CES responsible for managing the approval process and tracking system for all projects in the Census Bureau's Economic Directorate that use administrative records data. Brian Holly, CES Project Review Coordinator, now manages the approval process for projects that include activities crucial to the collection of the Census Bureau's surveys and censuses of businesses.

\subsection{Bob McGuckin, 1942-2006}

A great loss to the CES community and to economics was the death of Bob McGuckin in 2006. While Bob had left CES in 1996, he remained in close personal and professional contact with past and present CES staff, and retained a keen interest in CES activities. CES dedicated its 2005 annual research report to Bob's memory, and the report contained a tribute to him. A more contemporaneous view of his substantial contributions to CES, from the CES annual report for 1995-96, reproduced in Text Box 2, described McGuckin as "The Visionary Behind the Center for Economic Studies”. 
Text Box 2

From the CES Annual Report 1995-96 (1996):

“Bob McGuckin - The Visionary Behind the Center for Economic Studies

Although Bob McGuckin did not start the Center for Economic Studies, it was under his direction that CES reached its current form. Among the innovations he created or inspired:

- $\quad$ Research Data Centers

- CES Discussion Paper Series

- Longitudinal micro databases expanded far beyond the Longitudinal Research Database (LRD) and viewed as core Census Bureau resource

- Linked economic (establishment/firm) and demographic (household/individual) databases

- New data products including

o Index of High Technology Trade

o Product Diversification Indexes

o Gross Job Creation and Destruction Statistics”

\section{Looking ahead: 2007 and beyond}

Rapid change marked 2007. When the second of the two new Census Bureau headquarters buildings opened, CES was among the first divisions to move into it in January 2007. Lynn Riggs, the newly named Lead RDC Administrator, led the remodeling of the new RDC lab later that year. Reflecting the growing emphasis the Census Bureau has placed on data stewardship, CES created the position of CES Disclosure Officer, responsible for approving the release of statistics and other output from RDC research. Long-time CES staff member Arnold Reznek was named to this new position. Reznek had been the administrator of the RDC at Census Bureau headquarters, and a researcher in disclosure avoidance techniques whose expertise was frequently sought by the administrators of other RDCs.

In August 2007, Dan Weinberg left CES to become Assistant Director for the American Community Survey and Decennial Census. Ron Jarmin was named Acting Chief Economist. CES expanded after moving to the new Census Bureau headquarters building, adding two junior economists, a number of research assistants, and several members of the Data Staff. The Longitudinal Employer-Household Dynamics program became part of CES in March 2008. In 
June 2008, Ron Jarmin was named Chief Economist and Chief of the Center for Economic Studies.

Half a century ago visionaries representing both the Census Bureau and the external research community laid the foundation for CES and the RDC system. They saw a clear need for a system meeting the inextricably related requirements of providing more and better information from existing Census Bureau data collections while preserving respondent confidentiality and privacy. The CES and the RDC system meet those requirements. They meet the commitments of the Census Bureau (and, recently, of other agencies) to preserving confidentiality while contributing paradigm-shifting fundamental research in a range of disciplines and up-to-the-minute critical tools for decision-makers.

Our increasingly complex and interconnected economy and society require more information, on evolving topics, delivered in rapidly changing forms. Information technology changes at least as rapidly, constantly providing both new ways to collect and present information, and new threats, real and perceived, to the security of that information. The CES and RDC system of the future must continue to find new ways of meeting these fundamental responsibilities. 


\section{REFERENCES}

Adams, James D. and Elinor Champion. 1992. "Restructuring Research and Development Statistics at Census: A Blueprint for Change.” Presented at the meetings of the Census Advisory Committee of the American Economic Association, October 22-23.

Adams, James D. and Suzanne Peck. 1994. "A Guide to R\&D Data at the Center for Economic Studies U.S. Bureau of The Census.” Center for Economic Studies Discussion Paper CES-94-9.

Atrostic, B.K., John Gates, and Ron Jarmin. 2000. "Measuring the Electronic Economy: Current Status and Next Steps.” Center for Economic Studies Discussion Paper CES-00-10.

Bartelsman, Eric, Mark Doms, and Seppo Laaksonen. 2008. “A Brief History of CAED” at Comparative Analysis of Enterprise (Micro) Data-CAED.

$<$ www.upjohninst.org/caed/history.html $>$.

Bayard, Kimberly, Joel Elvery, Judith Hellerstein, and David Neumark. 2002. "The 1990 Decennial Employer-Employee Dataset.” Center for Economic Studies Discussion Paper CES02-23.

Bayard, Kimberly N. and Shawn D. Klimek. 2004. “Creating a Historical Bridge for Manufacturing between the Standard Industrial Classification System and the North American Industry Classification System.” American Statistical Association, 2003 Proceedings of the Business and Economic Statistics Section, 478-84.

Becker, Randy A. and Ronald J. Shadbegian. 2005. "A Change of PACE: Comparing the 1994 and 1999 Pollution Abatement Costs and Expenditures Surveys.” Journal of Economic and Social Measurement, 30(1): 63-95.

Black, Sandra E. and Lisa M. Lynch. 2001. "How to Compete: The Impact of Workplace Practices and Information Technology on Productivity.” The Review of Economics and Statistics, 83(3): 434-45.

Black, Sandra E. and Lisa M. Lynch. 2003. "The New Economy and the Organization of Work.” In New Economy Handbook, ed. Derek Jones. London, U.K.: Elsevier Science Academic Press.

Black, Sandra E. and Lisa M. Lynch. 2004. "What’s Driving the New Economy: The Benefits of Workplace Innovation.” The Economic Journal, 114(February): F97-F116.

Black, Sandra E. and Lisa M. Lynch. 2005. "Measuring Organizational Capital in the New Economy.” In Measuring Capital in the New Economy, ed. Carol Corrado, John C. Haltiwanger, and Daniel E. Sichel, 205-234. Chicago, IL: University of Chicago Press.

Black, Sandra E., Lisa M. Lynch, and Anya Krivelyova. 2004. "How Workers Fare When Employers Innovate.” Industrial Relations, 43(1): 44-66. 
Conklin, Maxwell R. 1964. “Time Series for Individual Plants from the Annual Survey of Manufactures and Related Data.” American Statistical Association, Proceedings of the Business and Economic Statistics Section, 404-10.

Conklin, Maxwell R. 1982. “Keynote Address.” In Development and Use of Longitudinal Establishment Data, Proceedings of the Workshop on the Development and Use of Longitudinal Establishment Data, January 14-15, Economic Research Report, ER-4.

Davis, James C., and Brian P. Holly. 2006. "Regional Analysis Using Census Bureau Microdata at the Center for Economic Studies.” International Regional Science Review, 29(3): 278-296.

Davis, Steven J. and John Haltiwanger. 1991. "Wage Dispersion Between and Within U.S. Manufacturing Plants, 1963-1986.” In Brookings Papers on Economic Activity: Microeconomics, ed. Martin Neil Baily and Clifford Winston, 115-200. Washington, DC: The Brookings Institution.

Davis, Steven J., John C. Haltiwanger, and Scott Schuh. 1994. Gross Job Flows in U.S. Manufacturing. U.S. Department of Commerce, U. S. Census Bureau, Center for Economic Studies. March 8.

Davis, Steven J., John C. Haltiwanger, and Scott Schuh. 1996. Job Creation and Destruction. Cambridge, MA and London, UK: The MIT Press.

Doyle, Patricia, Julia I. Lane, J.J. Theeuwes, and Laura V. Zayatz (eds). 2001. Confidentiality, Disclosure and Data Access: Theory and Practical Applications for Statistical Agencies. Amsterdam, Netherlands: North-Holland.

Duncan, George T., Thomas B. Jabine, and Virginia A. de Wolf. 1993. Private Lives and Public Policies: Confidentiality and Accessibility of Government Statistics. Washington DC: National Academy Press.

Feldstein, Martin, and Jeffrey Liebman. 2002. "The Distributional Effects of an InvestmentBased Social Security System.” The Distributional Aspects of Social Security and Social Security Reform. Ed. Martin Feldstein and Jeffrey Liebman. Chicago: University of Chicago Press.

Gollop, Frank, and James L. Monahan. 1989. From Homogeneity to Heterogeneity: An Index of Diversification. U.S. Bureau of the Census, Technical Paper 60. Washington, DC: U.S. Government Printing Office.

Govoni, John. 1982. "Methodological Problems Related to the Time Series File Developed from Census of Manufactures/Annual Survey of Manufactures.” In Development and Use of Longitudinal Establishment Data, Proceedings of the Workshop on the Development and Use of Longitudinal Establishment Data, January 14-15, Economic Research Report, ER-4. 
Greenia, Nicholas H. 2004. "Developing Adoptable Disclosure Protection Techniques: Lessons Learned From a U.S. Experience.” In Privacy in Statistical Databases, CASC Project International Workshop, PSD 2004, Barcelona, Spain, June 9-11, 2004: Proceedings, ed. Josep Domingo-Ferrer and Vicenç Torra, 343-352. New York: Springer.

Griliches, Zvi. 1980. "Returns to Research and Development Expenditures in the Private Sector." In New Developments in Productivity Measurement and Analysis, eds. John W. Kendrick and Beatrice N. Vaccara. Chicago, IL, and London, UK: The University of Chicago Press.

Griliches, Zvi, and Bronwyn Hall. 1982. “Census-NSF R\&D Data Match Project: a Progress Report.” In Development and Use of Longitudinal Establishment Data, Proceedings of the Workshop on the Development and Use of Longitudinal Establishment Data, January 14-15, Economic Research Report, ER-4.

Guerard, John B. Jr., Alsen S. Bean, and Steven Andrews. 1987. "R\&D Management and Corporate Financial Policy.” Management Science. 33(11): 1419-1427.

Hall, Bronwyn H., and William F. Long. 1999. "Differences in Reported R\&D Data on the NSF/Census RD-1 Form and the SEC 10-K Form: A Micro-Data Investigation.” Photocopy October 1997, revised October 1999.

Headd, Brian. 1999. “The Characteristics of Business Owners Database, 1992.” Center for Economic Studies Discussion Paper CES-99-8.

Ioannides, Yannis M. and Jeffrey E. Zabel. 2002. "Interactions, Neighborhood Selection and Housing Demand.” Center for Economic Studies Discussion Paper CES-02-19.

Jarmin, Ronald S. 1999. "Evaluating the Impact of Manufacturing Extension on Productivity Growth.” Journal of Policy Analysis and Measurement, 18(1): 99-119.

Kallek, Shirley. 1975. "Potential Applications of Census Bureau Economic Series in Microdata Analysis.” Papers and Proceedings of the American Economic Review, 65(2): 257-262.

Kallek, Shirley. 1982a. "Foreword.” In Development and Use of Longitudinal Establishment Data, Proceedings of the Workshop on the Development and Use of Longitudinal Establishment Data, January 14-15, Economic Research Report, ER-4.

Kallek, Shirley. 1982b. “Objectives and Framework.” In Development and Use of Longitudinal Establishment Data, Proceedings of the Workshop on the Development and Use of Longitudinal Establishment Data, January 14-15, Economic Research Report, ER-4.

Kallek, Shirley. 1983. “Oral History.” In Oral History: Interviews, <www.census.gov/prod/www/abs/oh.html>.

Kerr, William R. and Shihe Fu. 2006. “The Industry R\&D Survey: Patent Database Link Project.” Center for Economic Studies Discussion Paper CES-06-28. 
Kiel, Katherine A. and Zabel, Jeffrey E. 2004. "Location, Location, Location: The 3L Approach to House Price Determination.” Center for Economic Studies Discussion Paper CES-04-06.

Leibman, Jeffrey B. 2002. "Redistribution in the Current U.S. Social Security System.” Center for Economic Studies Discussion Paper CES-02-09.

Liebman, Jeffrey. "Redistribution in the Current U.S. Social Security System.” The Distributional Aspects of Social Security and Social Security Reform. Ed. Martin Feldstein and Jeffrey Liebman. Chicago, IL: University of Chicago Press, 2002.

Lynch, Lisa M. 2007. "The Adoption and Diffusion of Organizational Innovation: Evidence for the U.S. Economy.” Center for Economic Studies Discussion Paper CES-07-18 and National Bureau of Economic Research Working Paper w13156, June.

Maksimovic, Vojislav and Gordon Phillips. 2001. "The Market for Corporate Assets: Who Engages in Mergers and Asset Sales and Are There Efficiency Gains?” Journal of Finance, 56(6): 2019-2065.

McGuckin, Robert H. 1992. “Analytic Use of Economic Microdata: A Model for Researcher Access with Confidentiality Protection.” Proceedings of the International Seminar on Statistical Confidentiality.

McGuckin, Robert H., and George A., Pascoe Jr. 1988. “The Longitudinal Research Database (LRD): Status and Research Possibilities.” Survey of Current Business, 68(11): 30-37.

McGuckin, Robert H., and Sang V. Nguyen. 1990. "Public-Use Microdata: Disclosure and Usefulness.” Journal of Economic and Social Measurement, 16(1): 19-40.

McGuckin, Robert H., Sang V. Nguyen, and Arnold P. Reznek. 1995. "The Impact of Ownership Change on Employment, Wages, and Labor Productivity in U.S. Manufacturing 1977-87.” Center for Economic Studies Discussion Paper CES-95-8.

Miranda, Javier and Ron Jarmin. 2002. “The Longitudinal Business Database.” Center for Economic Studies Discussion Paper CES-02-17.

Nguyen, Sang V. 1998. “The Manufacturing Plant Ownership Change Database: Its Construction and Usefulness.” Journal of Economic and Social Measurement, 24(3\&4): 209232.

Nucci, Alfred. 1989. “The Characteristics of Business Owners (CBO) Database.” Center for Economic Studies Discussion Paper CES-89-9.

Report of the Census Advisory Committee. 1965. The American Economic Review, 55(1/2): 619620. 
Report of Representatives to the Social Science Research Council. 1960. The American Economic Review, 50(2): 722-723.

Ruggles, Richard, and Nancy D. Ruggles. 1984. "The Analysis of Longitudinal Establishment Data.” Presented at the Bureau of the Census and NSF Conference on Longitudinal Establishment Data File and Diversification Study, Alexandria, VA, October 17-18, 1984. 235267. Reprinted in Macro- and Microdata Analyses and their Integration. Cheltenham, UK and Northampton MA, USA: Edward Elgar.

Scherer, Fritz M. 1980. Industrial Market Structure and Economic Performance $2^{\text {nd }}$ ed. Boston, MA: Houghton-Mifflin.

Scherer, Fritz M. and David Ross. 1990. Industrial Market Structure and Economic Performance $3^{\text {rd }}$ ed. Boston, MA: Houghton-Mifflin.

Streitwieser, Mary. 1993. “Toxic Waste, Product Choice, and Plant Characteristics: The U.S. Chemical Industries.” Report to U.S. Department of Energy, Assistant Secretary of Energy Efficiency and Renewable Energy, Office of Industrial Technologies, Industrial Waste Reduction Program, Washington, D.C. December.

Streitwieser, Mary. 1996. "Evaluation and Use of the Pollution Abatement Costs and Expenditures Survey Microdata.” Center for Economic Studies Discussion Paper CES-96-1.

Triplett, Jack E., D. Mark Kennet, Ron Jarmin, and Frank M. Gollop. 1998. “Do Industrial Classifications need Re-Inventing? An analysis of the relevance of the U.S. SIC System for productivity research.” In Advances in Classification Research: Proceedings of the 6th ASIS SIG/CR Classification Research Workshop Held at the 58th ASIS Annual Meeting, Chicago, Illinois October 8, 1995, ed. Raymond P. Schwartz, Clare Beghtol, Elin K. Jacob, Barbara H. Kwasnik, and Philip J. Smith, 127-146. Medford, NJ: Information Today, Inc.

Troske, Kenneth R. 1998. “The Worker-Establishment Characteristics Database.” In Labor Statistics Measurement Issues, John Haltiwanger, Marilyn Manser and Robert Topel, eds., 371403. (Chicago: University of Chicago Press for NBER).

U.S. Census Bureau. 1992. “Center for Economic Studies, Bureau of The Census, Annual Report, Fiscal Year 1991.”

U.S. Census Bureau. 1994. "U.S. Bureau of The Census, Center for Economic Studies, Annual Report 1993-94.”

U.S. Census Bureau. 1996. “U.S. Bureau of The Census, Center for Economic Studies, Annual Report 1995-96.”

U.S. Census Bureau. 2005. "Research at the Center for Economic Studies and the Research Data Centers: 2000-2004.” Available at <ces.census.gov>. 
U.S. Census Bureau. 2006. "Research at the Center for Economic Studies and the Research Data Centers: 2005.” Available at <ces.census.gov> .

U.S. Census Bureau. 2007. "Research at the Center for Economic Studies and the Research Data Centers: 2005.” Available at <ces.census.gov>.

U.S. Census Bureau. 2008. “2007 Research Report: Center for Economic Studies and the Research Data Centers.” Available at <ces.census.gov>. 